\title{
Szorstki i chropowaty dotyk - o dramaturgii zmysłów
}

\begin{abstract}
Monika Błaszczak, Szorstki i chropowaty dotyk - o dramaturgii zmysłów [Rough and harsh touch - on the dramaturgy of the the senses]. „Przestrzenie Teorii" 36. Poznań 2021, Adam Mickiewicz University Press, pp. 227-253. ISSN 1644-6763. DOI 10.14746/pt.2021.36.14.

Today, the concept of dramaturgy refers primarily to the space of theater or, more broadly, to performative arts. But as the concept of drama has passed into the scientific discourse of sociology, anthropology or literary studies, so is it with dramaturgy. The understanding that appears here refers to its meaning as a special tension on the level of sensually experienced and perceived artistic events. The subject of interest here is the dramatic aesthetics of experience in the field of performing and visual arts. The aesthetic categories related to the senses are often of a physical origin and amorphous in nature. The roughness and harshness of the title in their origin are physical categories that can be experienced primarily through the sense of touch. In this intertwining of senses, we are talking about their dramaturgy, because they cannot usually be separated from each other and various works appeal to touch and other senses at the same time. The process of creating a work and its reception is an action, process, meeting, the playwright of which is both the creator / creator and the recipient. The considerations concern changes in the perception of the senses, from the glorification of the sense of sight to the ennoblement of the "lower" senses, the place and function of the classical and interactive museum and haptic art, as well as the polysensory and immersive reception designed in performance and theater.
\end{abstract}

KEYWORDS: rough, touch, senses, haptic, affect, dramaturgy, transcategories, museum, performance, mltisensory, immersion

Jeśli wybierasz się w podróż niech będzie to podróż dtuga wędrowanie pozornie bez celu bładzenie po omacku żebyś nie tylko oczami ale także dotykiem poznat szorstkość ziemi $i$ abyś cata skórq zmierzyt się ze światem ${ }^{1}$.

Czy można mówić o dramaturgii zmysłów? Pojęcie dramaturgii odnosi się dzisiaj przede wszystkim do przestrzeni teatru czy szerzej - sztuk performatywnych. Ale jak pojęcie dramatu przeszło do dyskursu naukowego: socjologicznego, antropologicznego czy literaturoznawczego, tak podobnie dzieje się z dramaturgią. Pojawiające się tu rozumienie dramatu odwołuje do jego znaczenia jako szczególnego napięcia na poziomie zmysłowo doświadczanych i postrzeganych zdarzeń artystycznych. Przedmiotem zainteresowania jest tu dramaturgiczna estetyka doświadczenia w obszarze sztuk performatywnych i wizualnych.

${ }^{1}$ Z. Herbert, Podróż, [w:] idem, Elegia na odejście, Wrocław 1993, s. 24. 


\section{Od gloryfikacji zmysłu wzroku do nobilitacji zmysłów "niższych"}

Kategorie estetyczne wiążące się ze zmysłami mają często źródło fizykalne i charakter amorficzny. Z pojęciem zmysłów sa ściśle powiązane teoria afektów i koncepcja żywiołów. Jednocześnie nie sposób nie odwołać się do pojęcia doświadczenia estetycznego, w którym obcowanie z dziełem sztuki, literatury, teatru czy sztuk performatywnych można postrzegać i analizować poprzez te właśnie kategorie. Szorstkość i chropowatość to w swym rodowodzie fizykalne kategorie możliwe do doświadczenia przede wszystkim poprzez zmysł dotyku. Choć można i tę szorstkość czy chropowatość zobaczyć na przykład na obrazach, to jednak gdyby istniała możliwość wejścia w interakcję z dziełem, wolelibyśmy dotknąć ich nieregularnej, pofałdowanej, wypukłej czy wklęsłej faktury, żeby w pełni ich doświadczyć. A dotyk to najbardziej zaniedbany zmysł, należy więc uważnie mu się przyjrzeć. W tym splocie zmysłów mowa o ich dramaturgii, gdyż zwykle nie da się ich od siebie oddzielić; różne dzieła odwołują się jednocześnie do dotyku i do innych zmysłów. Proces powstania dzieła i jego odbioru jest akcja, procesem, spotkaniem, którego dramaturgiem jest zarówno sam twórca (twórcy), jak i odbiorca.

Zaproponowane w tytule pojęcia mają wymiar transkategorii, jak je nazwała Mieke $\mathrm{Bal}^{2}$. W słownikach języka polskiego znajdziemy obok siebie terminy: „chropawość”, „chropowatość”, które są definiowane jako coś, co „ma na powierzchni dużo drobnych, twardych wypukłości. [...] Chropawy głos lub dźwięk jest niski, niemelodyjny i matowy. [...] Jako chropawe możemy określić coś, np. czyjś język lub sposób zachowania, co nie jest idealne i wymaga jeszcze pracy, aby stało się doskonalsze" ${ }^{3}$. Rzeczy szorstkie są definiowane podobnie, jako takie, które sa „pokryte drobnymi twardymi wypukłościami i bywają w dotyku nieprzyjemne. [...] Ktoś, kto jest szorstki, zachowuje się niedelikatnie. Także o słowach lub zachowaniu takiej osoby"4. W internetowym Słowniku języka polskiego PWN wskazano także na użycia tego słowa w stosunku do dźwięków i odgłosów: nieczyste, brzmiące przenikliwie ${ }^{5}$. Słowa „szorstki” i „chropowaty” mimo swej częściowej synonimiczności mają nieco inne zakresy znaczeniowe. „Szorstki”

${ }^{2}$ M. Bal, Wędrujace pojęcia w naukach humanistycznych. Krótki przewodnik, przeł. M. Bucholc, Warszawa 2012.

${ }^{3}$ Inny stownik języka polskiego, t. I: A...Ó, red. M. Bańko, Wydawnictwo Naukowe PWN, Warszawa 2000, s. 176.

${ }^{4}$ Inny stownik języka polskiego, t. II: P...Ż, red. M. Bańko, Wydawnictwo Naukowe PWN, Warszawa 2000, s. 759.

${ }^{5}$ Stownik języka polskiego PWN, https://sjp.pwn.pl/slowniki/szorstki.html (dostęp: 23.05.2020). 
dodatkowo występuje jako określenie niestosownego języka czy obcesowego sposobu mówienia (odnośnie czegoś nieprzyjemnego ${ }^{6}$ ). Te różne znaczenia mogą służyć jako tropy interpretacyjne w dalszych rozważaniach. Mówiąc o tym, co chropowate/szorstkie, należy zawsze mieć świadomość drugiego bieguna, czyli ich antonimii - gładkości

W tych wszystkich kontekstach, znaczeniach, perspektywach chciałabym ukazać na przykładach dramatyczny i dramaturgiczny charakter tytułowych kategorii. Z tego długiego wyliczenia językowych uwikłań terminów „chropowatość”, „szorstkość” i „gładkość” wyłania się splot nie tylko znaczeń, lecz także ich nacechowania emocjonalnego - dramaturgii emocji. „Chropowate” i „szorstkie” są często nacechowane negatywnie, dotycza tego, co nieprzyjemne, trudne, nieoczywiste, podczas gdy „gładkie” kojarzy się z tym, co pozytywne i przyjemne (choć może być jedynie pozorem, pod którym kryją się dwie pierwsze cechy). Warto prześledzić te konotacje w literaturze, teatrze i sztukach wizualnych w kontekście szerokiego ujęcia pojęcia dramaturgiczności.

\section{Muzeum klasyczne, czyli „Nie dotykaj!". Od wystawy za ozdobnym sznurem (w kapciach na nogach)...}

Obcowanie z dziełem sztuki w pierwszym skojarzeniu postrzegamy jako odbywajace się w przestrzeni muzeum czy galerii, polegające na patrzeniu na dzieło z pewnej odległości i obwarowane zakazem „nie dotykać!”. Jak słusznie zauważa współczesna badaczka i kuratorka sztuki Marta Smolińska: „Personel skwapliwie pilnuje zwiedzajacych, by zachowali odpowiedni dystans wobec dzieł sztuki i kontemplowali je jedynie wzrokiem. A tymczasem niektóre realizacje artystyczne kuszą i uwodzą także dotyk - nie pozostaje nam jednak nic innego, jak przestrzegać muzealnego regulaminu, dotykając dzieł jedynie spojrzeniem i wyobrażając sobie ich fakturę pod naszymi palcami...". Najlepszą ilustracją niezmienności tych odbiorczych wytycznych w wielu muzeach i galeriach będzie doświadczenie osobiste.

${ }^{6}$ Stownik synonimów, https://synonim.net/synonim/szorstki (dostęp: 23.05.2020).

${ }^{7}$ „Coś, co jest gładkie, ma powierzchnię pozbawioną jakichkolwiek nierówności. [...] Gładkie jezioro, morze, [...] Gładki materiał, papier itp. [...] Gładkie ubranie. [...] Gładkie uczesanie, włosy itp. [...] 6 Gładkie słowa i wypowiedzi są uprzejme i sprawiaja takie wrażenie, jakby przychodziły mówiącego bez trudu. [...] 7 Ktoś, kto jest gładki, jest miły i uprzejmy. Słowo nieco przestarzałe". Za: Inny słownik języka polskiego, t. I: A...Ó, ed. cit., s. 447-448.

${ }^{8}$ M. Smolińska, (Nie) dotykaj! Haptyczne aspekty sztuki polskiej po 1945 roku, https:// csw.torun.pl/sztuka/wystawy/wystawa-nwystawa-nie-dotykaj-haptyczne-aspekty-sztuki-polskiej-po-1945-rokuie-dotykaj-haptyczne-aspekty-sztuki-polskiej-po-1945-roku-4090/ (dostęp: 20.04.2021). 
Wchodzimy do wnętrza Zamku w Kórniku koło Poznania i na progu wita nas kosz z filcowymi kapciami. To pierwszy próg dostępu, poza oczywiście zakupieniem biletu. Potem wysokie schody bez jakichkolwiek udogodnień dla mniej sprawnych czy dziecięcych zwiedzajacych - drugi próg9. Wszystkie eksponaty sa pochowane w gablotach, witrynach, za szybami, sznurami i innymi elementami - trzeci próg. Do tego bardzo krótki czas otwarcia instytucji dla zwiedzajacych - w godzinach 10.00-16.00 - czwarty próg. Wiele muzeów nadal funkcjonuje na takich właśnie zasadach.

Należy jednak zauważyć, iż sytuacja powoli się zmienia. Wystawy interaktywne, w ramach których można doświadczać obcowania z artefaktami i dziełami sztuki przez pozostałe zmysły, w tym zwłaszcza przez dotyk, to coraz częściej pojawiające się formy kontaktu odbiorczego. Przestrzeń ekspozycji nie może już dziś być projektowana jako sfera tabu, w której wszystkie artefakty są dla odbiorcy nietykalne. Jednak wiele muzeów zamkowych czy wielkich galerii sztuki nadal utrzymuje taką formułę i na niewiele pozwala odwiedzającym je osobom. Wynika to z utrwalonych nawyków po obu stronach - i twórców, i odbiorców dzieł prezentowanych w ramach różnych ekspozycji. Tradycyjna definicja muzeum, od greckiego źródłosłowu mouseion - 'świątynia muz' i łacińskiego musaeum, mówi o „instytucji, której zadaniem jest gromadzenie i przechowywanie materialnych świadectw cywilizacji człowieka i jego otoczenia, ich naukowe opracowywanie, konserwowanie i udostępnianie w celu badań, nauczania i rozrywki" ${ }^{10}$. W tych definicjach podkreśla się, że prezentowane obiekty musza mieć wartość historyczną bądź artystyczną i że w większych placówkach tylko niewielka część zbiorów jest udostępniana publiczności $\mathrm{w}$ postaci wystaw stałych lub czasowych, a resztę przechowuje się w magazynach. W XX wieku muzea przekształciły się w aktywne placówki naukowe i oświatowe, zmodernizowano metody ekspozycji, wzniesiono wiele nowoczesnych gmachów muzealnych ${ }^{11}$.

Sami muzealnicy zauważają nieadekwatność tradycyjnego postrzegania tych instytucji i coraz częściej dostrzegają konieczność zmian. Na pytanie: „czym jest muzeum dzisiaj?” próbuje odpowiedzieć Dorota Folga-Januszew-

${ }^{9}$ Od tej wizyty sprzed kilku lat coś się jednak zmieniło - zamontowano windę. Zob. https:// kornik.travel/pl/obiekty/zwiedzanie/zamek-w-korniku?gclid=Cj0KCQjw9_mDBhCGARIsAN3PaFPpwAVNuWd0HkhoutucM8fSsYaBxs8vW3p5AsmInyRsLX2purAgLHQaAugTEALw_wcB (dostęp: 20.04.2021).

${ }^{10} \mathrm{https}: / /$ encyklopedia.pwn.pl/haslo/muzeum;3944738.html (dostęp: 23.04.2021).

${ }^{11}$ Ciekawym aspektem jest strona techniczna tworzenia wystaw i ekspozycji interaktywnych, otwartych na współuczestnictwo. Powstają firmy, które specjalizują się w przygotowywaniu takiego zaplecza, jak np. Multimedialne Muzeum, które jest marką agencji interaktywnej bozanta.pl, powstałej w 2009 roku. W ofercie ma multimedialne aplikacje, aranżacje ekspozycji czy oprawy graficznej. Zob. https://multimedialnemuzeum.pl/ (dostęp: 23.04.2021). 
ska, która cytuje Georges'a Henriego Rivière'a: „Muzeum jest instytucja trwała, o charakterze niedochodowym, służąca społeczeństwu i jego rozwojowi, dostępną publicznie, która prowadzi badania nad świadectwem ludzkiej działalności i otoczenia człowieka, gromadzi zbiory, konserwuje je i zabezpiecza, udostępnia je i wystawia, prowadzi działalność edukacyjna i służy rozrywce" ${ }^{12}$. Muzea należałoby jednak dostosować do współczesnych realiów, zwłaszcza rewolucji elektronicznej, która dostarczyła narzędzi właściwie nieograniczonego gromadzenia danych: wizerunków, dokumentów, programów, wszelkich zapisów. Potencjalnie każda większa elektroniczna baza danych jest wirtualnym muzeum lub archiwum z jakiejś dziedziny. W latach dziewięćdziesiątych XX wieku pojawiło się pojęcie „muzeum wirtualnego". Takie placówki mogą wypełniać wszystkie funkcje wymienione w wyżej cytowanej definicji muzeów. Przede wszystkim jednak do zadań muzeów wymienionych na wstępie dochodzi działalność kreacyjna - tworzenia kultury, rzeczywistości, czasem sztuki realizowanej w cyfrowym obszarze wirtualnym ${ }^{13}$. Muzeum interaktywne jest definiowane jako „zlokalizowane $\mathrm{w}$ przestrzeni rzeczywistej (tj. w konkretnym budynku lub pomieszczeniu) nowoczesne muzeum, którego głównym zadaniem jest wieloperspektywiczne przekazanie zwiedzającym jakiejś idei, zdarzeń, zagadnień, które wykorzystuje do tego celu ekspozycje stworzone z różnych środków przekazu, takich jak: multimedia (filmy, muzyka, prezentacje multimedialne, wizualizacje), oryginalne eksponaty i fotografie czy interaktywne formy prezentacji (scenografia, repliki, makiety, których każdy może dotknąć)"14. Najważniejszy w nich jest bezpośredni kontakt, czyli interakcja między widzem a ekspozycja, oddziałująca w sposób polisensoryczny, czyli na różne zmysły zwiedzającego (wzrok, słuch, węch, dotyk, smak).

Bardzo ciekawą koncepcję muzeum krytycznego przedstawił Piotr Piotrowski w książce będącej podsumowaniem jego pracy w Muzeum Narodowym w Warszawie. Zwraca w niej uwagę na potrzebę muzeum rozumianego jako forum zaangażowane w debatę publiczna, podejmujące ważne problemy (często kontrowersyjne), którymi żyje społeczeństwo, postrzeganego jako instytucja pracująca na rzecz demokracji opartej na sporze. Muzeum krytyczne to także instytucja autokrytyczna, rewidująca własną tradycję, mierząca się z własnym autorytetem oraz kanonem historyczno-artystycznym, który sama ukształtowała ${ }^{15}$.

${ }^{12}$ G.H. Rivière, La muséologie selon, Paris 1989, [cyt. za:] D. Folga-Januszewska, Muzeum: definicja i pojęcie. Czym jest muzeum dzisiaj?, „Muzealnictwo” 2008, nr 49, s. 200.

${ }^{13}$ D. Folga-Januszewska, op. cit., s. 200, 201.

${ }^{14}$ M. Stefanik, M. Kamel, Muzea i wystawy interaktywne w Polsce-wspótczesna atrakcja turystyczna, „Turystyka Kulturowa” 2013, nr 8, s. 9.

${ }^{15}$ P. Piotrowski, Muzeum krytyczne, Poznań 2011. 
A przecież nie chodzi o to, żebyśmy dotykali cennych obrazów czy rzeźb, ale żeby nam zostawiono miejsce na jakaśs inną zmysłową aktywność poza patrzeniem. Jak pisze Maria Popczyk, wizja muzeum przeszła ewolucję i współcześnie najbardziej adekwatne wydaje się „porzucenie myślenia o muzeum jako miejscu zachowującym te same co w XIX wieku sposoby podejścia do artefaktów przyrody i dzieł sztuki oraz wykazanie, że w muzeum dokonuje się daleko idące przeformułowanie tego podejścia. Jest oczywiste, że jako sprawnie działająca instytucja muzeum podlega modernizacji, która zawsze w jakimś stopniu dotyczy ekspozycji, chodzi jednak o coś więcej, mianowicie wraz z tymi zmianami samo muzeum zyskuje nowa postać, nie jest już autonomicznym miejscem kontemplacji dzieł, jak twierdzi Odo Marquard czy Arthur Danto, ale staje się miejscem interakcji z odbiorcą"16.

\section{... do ekspozycji haptycznych. Muzeum interaktywne/ performatywne, czyli "Działaj i dotknij"}

Zatem muzea i galerie stają się współcześnie miejscami pełniącymi nie tylko funkcję archiwów, czyli ochronna, która polega na tym, że gromadzi się i przechowuje cenne artefakty i dzieła sztuki. Coraz częściej realizacja podstawowych funkcji tych miejsc opiera się nie na przechadzaniu się po salach i oglądaniu ekspozycji z zachowaniem odpowiedniego dystansu pod czujnym okiem osób pilnujących, by tej granicy nie naruszyć, ale na działaniu, interakcji, wejściu $\mathrm{w}$ bliższą relację z eksponatami, $\mathrm{z}$ opowiadana przez nie historia, z estetyką miejsca i pracownikami. Funkcje: edukacyjna, naukowa, kulturalna, wychowawcza i estetyczna zyskują swój nowy, dużo bardziej „namacalny” wymiar.

Pojawiaja się interaktywne, a nawet performatywne miejsca kontaktu z dziełami sztuki i śladami przeszłości. Przykłady można mnożyć, bo jest to obecnie silny trend: Brama Poznania, czyli ICHOT ${ }^{17}$, Muzeum Powstania Warszawskiego ${ }^{18}$, Muzeum Krakowa ${ }^{19}$, Centrum Nauki Kopernik ${ }^{20}$ czy

${ }^{16}$ M. Popczyk, Estetyczne przestrzenie ekspozycji muzealnych. Artefakty przyrody i dzieła sztuki, Kraków 2008, s. 10.

17 „Brama Poznania to przede wszystkim ekspozycja. Myli się jednak ten, kto myśli, że będzie to kolejne nudne zwiedzanie pod hasłem «Nie dotykać!». U nas jest odwrotnie. Zachęcamy: zakrecé, przymierz, zagraj, dotknij”. Zob. https://bramapoznania.pl/oferta-dla-rodzin-z-dziecmi (dostęp: 23.04.2021).

${ }^{18} \mathrm{https} / / /$ www.1944.pl/artykul/tajne-komplety-czyli-zwiedzaj-muzeum-inaczej-ni,5114. html (dostęp: 23.04.2021).

${ }^{19} \mathrm{https} / / /$ muzeumkrakowa.pl/cykle/program-edukacyjny-towarzyszacy-wystawie-w-chocholim-tancu (dostęp: 23.04.2021).

${ }^{20}$ https://www.kopernik.org.pl/wydarzenia (dostęp: 23.04.2021). 
Muzeum Bajek, Baśni i Opowieści MuBaBao w Czarnowie ${ }^{21}$. Poza tym trzeba podkreślić, iż muzea i galerie sztuki to nie tylko budynki, lecz także tereny postindustrialne, parki, ogrody czy inne otwarte przestrzenie, które przez swój nietypowy charakter otwierają się na inny sposób komunikacji i relacji z odbiorca.

Otwarcie na odbiorcę to znoszenie wymienionych na początku progów: od tych najoczywistszych, czyli architektonicznych, przez filcowe kapcie, złocone sznury i szklane witryny, po dopuszczenie publiczności do głosu i działania, czyli do aktywności, współkreowania, uruchamiania wszystkich zmysłów. Choć warto tu też zauważyć, że najwięcej miejsca na eksplorację przez działanie dostaja dzieci, dla których w wielu takich przestrzeniach pojawiaja się miejsca do aktywnego uczestnictwa, dodatkowych zabaw edukacyjnych czy bardziej interaktywnego zwiedzania.

Coraz częściej pojawiaja się wystawy i projekty performatywne adresowane do osób niewidzących i niedowidzących, mocno odwołujące się nie tylko do sfery dźwiękowej, lecz także dotykowej. W 2013 roku zorganizowano wystawę Dotknać obrazu - Malczewski, Szymborska, Antoniszczak ${ }^{22}$ w ramach szerszego projektu pod nazwa Dotknij kultury. We wspomnianym już Muzeum Historycznym Miasta Krakowa, mającym niezwykle szeroką ofertę działań i współuczestnictwa (warsztaty, oprowadzenia kuratorskie i tematyczne, spacery, wycieczki rowerowe, dyskusje czy panele), ten aspekt też jest mocno eksponowany. Szczególnie ciekawym pomyłem jest aranżacja wystawy Kraków - czas okupacji 1939-1945 w oddziale Fabryka Schindlera, udostępniona widzom z niepełnosprawnością wzroku i słuchu w ramach programu Deklaracji dostępności. Jak piszą na stronie wydarzenia organizatorzy: „Jest to pierwsze tego typu przedsięwzięcie w Muzeum Historycznym Miasta Krakowa, przygotowane we współpracy z Fundacją Kultury bez Barier i Fundacją Dzieciom Zdążyć z Pomoca w ramach projektu Muzeum Poza Ciszą i Ciemnością dofinansowanego przez Ministra Kultury i Dziedzictwa Narodowego. Poniżej zamieszczone zostały pliki mp3 z audiodeskrypcją wystawy, do pobrania na telefon lub odtwarzacz mp3. Każdy z audiodeskrypcyjnych tekstów składa się z dwóch części - opisu sali lub konkretnego eksponatu oraz opisu merytorycznego prezentowanego na wystawie zagadnienia. Podczas zwiedzania wystawy osoby niedowidzące i niewidome będą mogły również skorzystać z materiałów tyflograficznych, czyli wypukłych modeli ułatwiających odtworzenie

${ }^{21} \mathrm{https} / / / \mathrm{www}$.facebook.com/Muzeum-Bajek-Ba\%C5\%9Bni-i-Opowie\%C5\%9Bci-Storyteller-Museum-128032343954199; http://mubabao.pl/ (dostęp: 23.04.2021).

${ }^{22}$ Dotknać obrazu - Malczewski, Szymborska, Antoniszczak, Muzeum UJ Collegium Maius, 14.10 - 6.12.2013, http://www.dotknijkultury.pl/pl/poprzednie-edycje/2013/wydarzenia/ wystawa-dotknac-obrazu (dostęp: 7.07.2020). 
w wyobraźni wybranych elementów ekspozycji. Dla osób niesłyszących i niedosłyszących przygotowane zostały wideo tłumaczenia (na język migowy) oraz napisy do wybranych prezentacji multimedialnych i filmów, a także opracowano przewodnik po dźwiękach wystawy, które tworza jej integralną część, a bez których jej odbiór jest niepełny”"23. Takie podejście staje się coraz bardziej powszechne, czego przykładem może być poznański projekt realizowany przez Centrum Kultury Zamek Sztuka w ciemno. Cykl zdalnych warsztatów sensualnych ${ }^{24}$.

Ciekawym zjawiskiem, które zmienia sposób odbioru na polisensoryczny, jest sztuka haptyczna. Różnica między zmodernizowaniem odbioru tradycyjnych artefaktów i dzieł sztuki a sztuką haptyczną polega na tym, że ta druga zakłada jako podstawę odbioru dotyk. Aneta Rostkowska, współczesna badaczka i kuratorka sztuki, definiuje sztukę haptyczna jako „dzieła sztuki, których głównym sposobem doświadczenia jest zmysł dotyku”, odróżniając je jednocześnie od „dzieł sztuki, których jednym z głównych tematów jest zmysł dotyku". Haptyczne dzieło sztuki należy do tej pierwszej kategorii, a więc jako takie, które ukazuje się w pełni dopiero w kontakcie dotykowym, a „odbiór dzieła z pominięciem tego zmysłu spowoduje niepełne uobecnienie się w doświadczeniu odbiorcy"25. Od strony przedmiotowej dzieło tego typu charakteryzuje się głównie własnościami, których można bezpośrednio doświadczyć jedynie z użyciem zmysłu dotyku, takimi jak: miękkość/twardość, mniejsza lub większa spoistość, własności termiczne (ciepło/zimno), mokre/suche, sztywność/giętkość, napięcie/luźność, śliskość/opór, kruchośćl siła, lekkość/ciężkość (jeśli źródłem dotyku jest sam artysta - czego można doświadczyć na przykład w performansie - do tej listy można dodać specyficzne rodzaje dotyku: głaskanie, popychanie, obejmowanie, policzek itd.). „Zmysł dotyku nie jest w nim potraktowany czysto instrumentalnie, a więc jako środek dotarcia do własności innego, niedotykowego typu, lecz jako istotny środek dotarcia do treści dzieła" ${ }^{26}$.

Z kolei Marta Smolińska, inna badaczka haptyczności, była kuratorka wystawy o znamiennym tytule (Nie) Dotykaj! Haptyczne aspekty sztuki polskiej po 1945 roku, prezentowanej w Centrum Sztuki Współczesnej w Toruniu w $2015 \mathrm{roku}^{27}$. Ekspozycja została podzielona na dwie części: w pierwszej

${ }^{23} \mathrm{https}$ ://muzeumkrakowa.pl/muzeum-bez-barier (dostęp: 20.04.2021).

${ }^{24} \mathrm{https}: / /$ sztukawciemno.pl/ (dostęp: 20.04.2021).

${ }^{25}$ A. Rostkowska, Haptyczne dzieło sztuki, [w:] Materia sztuki, red. M. Ostrowicki, Kraków 2010, s. 298, 300.

${ }^{26}$ Ibidem, s. 300.

${ }^{27}$ Wystawa (Nie) Dotykaj! Haptyczne aspekty sztuki polskiej po 1945 roku była prezentowana w Centrum Sztuki Współczesnej w Toruniu w dniach 11.04 - 17.05.2015. Artyści: Basia Bańda, Marcin Berdyszak, Beata Ewa Białecka, Tomasz Ciecierski, Dawid Czycz, Iwona Demko, Barbara Falender, Krzysztof Gliszczyński, Martyna Grzeszczak, Małgorzata 
odbiorcy mogli dotykać dzieł sztuki realnie, w drugiej - jedynie wzrokiem. Kuratorka tak tłumaczyła swoją koncepcję: „Pojęcie 'haptyczny' (od greckiego haptein) oznacza zarówno chwytanie i dotykanie w dosłownym sensie, jak i dotykanie wzrokiem, uczucie 'jakby się dotykało'. [...] Pierwsza z nich umożliwia odbiorcom realny, dotykowy kontakt z wybranymi dziełami [...]. Jest zaaranżowana niczym otwarty 'plac zabaw', na którym zwiedzający moga wchodzić w interakcje z wystawionymi pracami (oczywiście w sposób zgodny z instrukcjami sformułowanymi przez twórców). Druga zaś prezentuje takie dzieła, które wyjątkowo silnie uwodzą zmysł dotyku, lecz moga być dotykane jedynie wzrokiem [...]. Napięcie pomiędzy uwodzeniem dotyku a niemożnością realnego dotknięcia wynika w tym wypadku najczęściej z potrzeby chronienia dzieł przed zniszczeniem"28. Dramaturgia polega tu na uruchomieniu cielesności percepcji - poprzez skórę jako powierzchnię dotyku. Odbiór takiej sztuki jest zatem somatyczny, odwołuje się do tego, co intuicyjne i emocjonalne.

Owa badaczka i historyczka sztuki w wydanej niedawno książce Haptyczność poszerzona. Zmyst dotyku w sztuce polskiej drugiej połowy XX i poczatku XXI wieku ${ }^{29}$ tytułową haptyczność widzi bardzo szeroko: „bardziej interesuje mnie zatem kwestia w pewnym sensie odwrotna: co wydarzy się z percepcja gdy - zamiast sztucznie oddzielać od siebie doznania zmysłowe - spojrzeć na nie całościowo wraz z udziałem słuchu, smaku i węchu oraz zmysłów równowagi i kinestetycznego. Jak wielozmysłowa, poszerzona i somaestetyczna definicję haptyczności trzeba byłoby wówczas zaproponować, by opisała ona wieloaspektowość tych wrażeń, obejmujacych całe ciało?"30. Haptyczność staje się dla niej modalnością wzroku, lecz również słuchu, smaku i węchu, a także zmysłu równowagi i zmysłu kinestetycznego (propriocepcja). Badaczka wskazuje na „multisensoryczny, somaestetyczny i synestetyczny wymiar haptyczności”31. Powołuje się przy tym na inspirację,

\footnotetext{
Kalinowska, Bartosz Kokosiński, Maciej Kurak \& Max Skorwider, Kamil Kuskowski, Paweł Łubowski, Karina Marusińska, Paweł Matyszewski, Magda Moskwa, Justyna Olszewska, Ewa Partum, Włodzimierz Pawlak, Andrzej Pawłowski, Maria Pinińska-Bereś, Krystyna Piotrowska, Damian Reniszyn, Erna Rosenstein, Aleksandra Ska, Marian Stępak, Alina Szapocznikow, Beata Szczepaniak, Grzegorz Sztwiertnia. Zob. https://csw.torun.pl/sztuka/ wystawy/wystawa-nwystawa-nie-dotykaj-haptyczne-aspekty-sztuki-polskiej-po-1945-rokuie-dotykaj-haptyczne-aspekty-sztuki-polskiej-po-1945-roku-4090/ (dostęp: 23.04.2021).

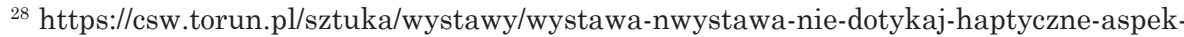
ty-sztuki-polskiej-po-1945-rokuie-dotykaj-haptyczne-aspekty-sztuki-polskiej-po-1945-roku-4090/ (dostęp: 23.04.2021).

${ }^{29}$ M. Smolińska, Wprowadzenie, [w:] eadem, Haptyczność poszerzona. Zmyst dotyku w sztuce polskiej drugiej połowy XX i poczatku XXI wieku, Kraków 2020.

${ }^{30}$ Ibidem, s. 13.

${ }^{31}$ Ibidem, s. 13.
} 
jaką jest tekst Wojciecha Bałusa ${ }^{32}$, który wskazał dotykanie wzrokiem jako istotę haptyczności w ramach klasycznej nauki o sztuce. Badacz wywiódł poglądy Aloisa Riegla z tekstów Adolfa Hildebranda i Roberta Vischera, którzy pisali o „symbolicznym” czy metaforycznym traktowaniu dotyku i uruchamianiu go w ramach tzw. aktywnego patrzenia, wykorzystującego zapamiętane wrażenia dotykowe.

Zmysły od wieków dzielono na tzw. wyższe - wzrok i słuch oraz niższe - smak, węch, dotyk. Na polu filozoficznym i estetycznym przez wieki toczyły się spory o istotę piękna i wagę poszczególnych zmysłów. Wzrok był zmysłem uprzywilejowanym. „Estetyka wizualna to opowieść snuta przez barwy i kształty, które "wiążą", "przytrzymują" nasze spojrzenie, które nasze oko napotyka i przy których zatrzymuje się na dłużej"33. Następny co do ważności po wzroku był słuch. Starożytni Grecy uważali, że jedynie uszy będą w stanie usłyszeć harmonię, a oczy dostrzegą symetrię. Zmysły dotyku, smaku i węchu były nazywane nie tylko niższymi, lecz także ciemnymi i kanibalistycznymi, związanymi z instynktem przeżycia, cielesnościa, materialnością bytu, z ludzką natura tą bardziej zwierzęca, cielesna, mniej cywilizowana. Autorstwo tradycyjnego modelu pięciu zmysłów (wzrok, słuch, dotyk, zapach, smak) jest przypisywane Arystotelesowi. Filozof podkreślał uprzywilejowane miejsce wzroku na tle pozostałych zmysłów, jednocześnie dostrzegając ważną rolę dotyku w zdolności przetrwania ${ }^{34}$. Analizując relację poznania, dostrzegał przede wszystkim, iż wszelkie informacje docieraja do nas poprzez zmysły. Rzeczywiste poznanie świata ma naturę pojęciowa, ale aby coś zrozumieć i stworzyć tego pojęcie, musimy najpierw doświadczyć tego zmysłami. Rodzimy się bowiem, nie będąc wyposażonymi w żadne terminy i idee; tylko zmysły moga je nam udostępnić i unaocznić.

Długo uważano, że człowiek jest w stanie doświadczyć przeżycia estetycznego za pomocą zmysłów wyższych, czyli wzroku i słuchu, zwierzęta natomiast mogą czerpać przyjemność za pośrednictwem zmysłów niższych: smaku i dotyku ${ }^{35}$. Poza tym wzrok i słuch postrzegano jako zmysły niezbęd-

${ }^{32}$ W. Bałus, Dotykanie wzrokiem. O pojęciu haptyczności w klasycznej nauce o sztuce, „Konteksty” 2019, nr 4, s. 202.

${ }^{33}$ M. Podgórski, Ucieczka od wizualności i jej społeczne konsekwencje. Fenomen estetyki haptycznej, Poznań 2011, s. 18.

${ }^{34}$ Arystoteles, $O$ duszy, przeł. P. Siwek, Warszawa 1992.

${ }^{35}$ Odnosząc się do wiedzy z zakresu biologii, trzeba stwierdzić, iż nie mamy tak wysokiej wrażliwości tzw. zmysłów niższych jak inne gatunki. Człowiek nie wykształcił takich zmysłów jak magnetyczny, wibracyjny czy elektryczny, choć badacze wymieniają też wiele dodatkowych zmysłów u ludzi, m.in. propriocepcję, nocycepcję, termocepcję, zmysł równowagi, chemoreceptory czy magnetorecepcję. Ciekawym zjawiskiem jest też doświadczanie przez niektórych ludzi tzw. synestezji - stanu, w którym doświadczenia jednego zmysłu (np. wzroku) wywołują doświadczenia charakterystyczne dla innych zmysłów. Szerzej na 
ne do przetrwania ${ }^{36}$. Myśl klasyczna postrzegała sztukę jako narzędzie duchowego oczyszczenia. Zmysł dotyku, jako ten dotyczący ciała i cielesności, przez całe wieki był traktowany jako „gorszy”, przyziemny, niski. Bernard z Clairvaux głosił tezę o wyższości piękna wewnętrznego, a św. Tomasz z Akwinu przeciwstawiał przeżycie estetyczne „zwykłemu postrzeganiu i uwarunkowanym biologicznie czynnościom" ${ }^{37}$. W Iconologii Cesare Ripy ${ }^{38}$ z 1593 roku po raz pierwszy pojawiło się natomiast stwierdzenie, że dotyk nie musi być przyjemny - może bowiem wiązać się także z bólem. Dla Hegla jedynie wzrok zasługiwał na miano najszlachetniejszego ze zmysłów - jako zmysł duchowy i intelektualny, czyli pozwalajacy na zachowanie dystansu poprzez obserwację z pewnej odległości. Hegel określa zmysły wzroku i słuchu jako „teoretyczne” - w etymologii greckiego słowa theoria mamy odwołanie właśnie do sfery wizualnej. Greckie słowo háptein oznacza natomiast: 'złapać', 'przymocować', 'wiązać', co sugeruje fizyczny kontakt z przedmiotem.

Za początek uprzywilejowania zmysłów niższych można uznać osiemnastowieczne rozważania Aleksandra Baumgartena, który jako pierwszy utożsamia poznanie zmysłowe z poznaniem piękna, tworząc tym samym tak bliskie nam obecnie pojęcie „estetyki” ${ }^{39}$. Zmysły stawały się coraz częstszymi przedmiotami rozważań i niekoniecznie ograniczały się do samego wzroku, postrzegania - wciąż jednak dzielono je na te wyższe i te pierwotne. Krytykę nobilitacji zmysłu wzroku spotkamy u osiemnastowiecznego filozofa Maine de Birana. Twierdził on, że dotyk jest zmysłem, który umożliwia nam bezpośredni kontakt ze światem. Dotyku nie da się oszukać - reinterpretuje on wrażenie wywołane zderzeniem z rzeczywistym obiektem ${ }^{40}$. Podobne poglądy miał wspomniany już filozof Johann Gottfried Herder, który mówił o zmyśle wzroku: „Zmysł wzroku dostarczy nam [...] większość idei dotyczacych powierzchni rzeczy, a zatem większość przesądów: za jego to sprawą niebo

ten temat pisza: M. Koton-Czarnecka, Zmysty zwierzat sq niesamowite. Jak postrzegaja świat?, „National Geographic Polska” 25.02.2020, https://www.national-geographic.pl/artykul/zmyslowa-ostrosc (dostęp: 8.03.2020); Człowiek posiada znacznie więcej niż 5 zmysłów, 16.06.2016, https://joemonster.org/art/36446, źródło anglojęzyczne: D. Hiskey, Humans have a lot more than five senses, 16.07.2010, http://www.todayifoundout.com/index.php/2010/07/ humans-have-a-lot-more-than-five-senses/ (dostęp: 3.08.2020); A. Mączyńska-Frydryszek, M. Jaskólska-Klaus, T. Maruszewski, Psychofizjologia widzenia, red. R. Bartel, Poznań 2001.

${ }^{36}$ W. Tatarkiewicz, Dzieje sześciu pojęć: sztuka, piękno, forma, twórczość, odtwórczość, przeżycie estetyczne, red. E. Nowakowska, Warszawa 1975.

${ }^{37}$ Ibidem, s. 401.

${ }^{38}$ C. Ripa, Ikonologia, Kraków 2013.

${ }^{39}$ A.G. Baumgarten, Metafizyka, przeł. i oprac. J. Surzyn, seria Biblioteka Europejska, Kęty 2012. Zob. też: P. Kozak, Wychować Boga. Estetyka antropologiczna Alexandra Gottlieba Baumgartena na tle myśli niemieckiej pierwszej połowy XVIII wieku, Warszawa 2013.

${ }^{40}$ Ibidem, s. 131. 
stawało się firmamentem, chmury - stadem baranów, księżyc - błyszcząca tarczą itd. Zdarza się powszechnie, że to, co widzimy tylko za pomocą wzroku, widzimy w sposób fałszywy, błędny" ${ }^{41}$. To on sparafrazował słynną myśl Kartezjusza w słowach: „Czuję siebie! Jestem!”, wyznaczając tym samym punkt centralny swoich refleksji estetycznych.

Dopiero w XX wieku, między innymi za sprawą rosnącego zainteresowania artystów, powstały teorie estetyczne akcentujące udział całej ludzkiej zmysłowości w doświadczeniu estetycznym i dzięki temu kwestionujące stereotypy towarzyszace zmysłowi dotyku ${ }^{42}$. Estetyk Karl Aschenbrenner ${ }^{43}$ dokonał klasyfikacji zmysłów, wedle której odczucia związane ze smakiem, z temperaturą i zapachem należą do tych niższego rzędu, będących jedynie tłem dla prawdziwego przeżycia estetycznego, zapewnianego nam przez wzrok i słuch. Odnosząc się do jego słów, Maria Gołaszewska w Estetyce pięciu zmysłów pisze: „Tu także należą doznania owych zmysłów «niższych»: zapachy, doznania dotykowe, smakowe, wrażenia somatyczne i kinetyczne, które - zależnie od charakteru - ułatwiają czy umożliwiaja, albo znacznie utrudniają koncentrację na tym, co znajduje się na pierwszym planie naszej percepcji czy koncentracji intelektualnej”"44. Jedna z takich teorii jest zapoczątkowana przez Johna Deweya, a rozwijana obecnie przez amerykańskiego filozofa Richarda Shustermana estetyka pragmatyczna. Z perspektywy pragmatycznej poniższe rozważania nad dotykowymi kategoriami mają na celu nie tylko uchwycenie funkcjonowania tego zmysłu w sztuce, lecz także wzbogacenie procesów powstawania i oddziaływania samej sztuki. Badacz proponuje nową dziedzinę wiedzy - „somatoestetykę”, w założeniu obejmujacca „krytyczne i mające na celu doskonalenie badania nad doświadczaniem i wykorzystywaniem ciała jako ośrodka zmysłowo-estetycznego wartościowania (aisthesis) i twórczej autokreacji” ${ }^{45}$.

${ }^{41}$ Cytat przytoczony przez Krzysztofa Tkaczyka w tekście Johann Gottfried Herder. Sensualistyczny bunt wobec klasycznej estetyki, [w:] W kulturze dotyku? Dotyk i jego reprezentacje $w$ tekstach kultury, red. A. Łebkowska, Ł. Wróblewski, P. Badysiak, Kraków 2016, s. 20.

${ }^{42}$ Warto tu podkreślić, że w kulturach pozaeuropejskich ta kwestia wygląda inaczej: doświadczenie estetyczne jest ujmowane jako angażujące całość cielesnej egzystencji człowieka. Przykładem może być japońska ceremonia parzenia herbaty, w której oprócz walorów wizualnych i smakowych istotne są aspekty haptyczne (np. doznanie faktury naczynia wypełnionego naparem).

${ }^{43}$ K. Aschenbrenner, Jak możliwa jest sztuka?, przeł. M. Gołaszewska, [w:] Eseje o pięknie. Problemy estetyki i teorii sztuki, red. K. Wilkoszewska, Warszawa-Kraków 1988; [także w:] Eidos sztuki, red. M. Gołaszewska, Kraków 1988.

${ }^{44}$ M. Gołaszewska, Estetyka pięciu zmystów, Warszawa-Kraków 1997, s. 117.

${ }^{45}$ R. Shusterman, Estetyka pragmatyczna. Żywe piękno i refleksja nad sztuka, red. nauk. A. Chmielewski, przeł. A. Chmielewski i in., Wrocław 1998, s. 138. 


\section{Dotyk sceny, czyli odbiorca w uścisku performansu i spektaklu}

Jak słusznie zauważa współczesna badaczka performansu: „Ograniczając się jedynie do zmysłu wzroku, umniejszamy nasze człowieczeństwo. W poprzek tej powszechnej tendencji występuje dotyk - jako interakcja z rzeczywistością [...], jako pragnienie kontaktu z realną rzeczywistościa i pominięcie powszechnej retoryki iluzji, wreszcie jako wyjście z usankcjonowanych społecznie reguł istnienia” ${ }^{46}$. Nazywa wzrok „,zmysłem dystansu i narzędziem iluzji" ${ }^{47}$, dotyk natomiast postrzega jako metodę odejścia od iluzoryczności i „wejścia w bezpośredniość, a przede wszystkim wzajemność"

Klasyczny już performans najbardziej znanej i opisanej artystki tej sztuki, Mariny Abramović, będzie najlepszą ilustracją tych słów. Imponderabilia z 1977 roku to performans, którego koncepcja zakładała mocne skrócenie dystansu i wejście w bezpośredni kontakt z odbiorca. Podstawa jego stworzenia była bliska relacja artystów - Mariny oraz jej życiowego i artystycznego partnera Uwego Laysiepena, nazywanego Ulayem. Przez dekadę stworzyli oni serię prac ikonicznych dla historii body artu. Głównym celem ich życiowo-artystycznego związu było eksplorowanie cielesności, $\mathrm{w}$ tym zanegowanie podziału na dwie płcie. W performansie Imponderabilia Ulay i Marina stali nago po przeciwległych stronach futryny w waskim przejściu w przestrzeni Muzeum Galleria d’Arte Moderna w Bolonii, a pomiędzy nimi musieli przeciskać się widzowie, dokonując równocześnie wyboru, do kogo odwrócić się twarzą. Luka między ich ciałami została określona jako metafora kanału rodnego. Performans miał trwać trzy godziny, ale został przerwany przez policję po zaledwie dziewięćdziesięciu minutach, ponieważ uznano go za obsceniczny. Artyści specjalnie przekraczali granicę komfortu, żeby pokazać, jak bardzo współczesna kultura powoduje, że nie jesteśmy przygotowani na kontakt $\mathrm{z}$ drugim człowiekiem, oraz jak bardzo stabuizowane są nagość i intymność. Performans mocno skracał dystans pomiędzy twórca, dziełem a odbiorca, angażując silnie zmysły, w tym zwłaszcza „prowokując" zmysł dotyku.

Artystka od lat poddaje swoje ciało ekstremalnym doświadczeniom i wprowadza widzów/uczestników swoich dzieł w skrajne stany emocjonalne. Konsekwentnie redefiniuje to, czym jest i czym może być sztuka współczesna, a jej narzędziem jest własne ciało, którego granice i wytrzymałość bezwzględnie testuje. Przeprowadza na nim artystyczne eksperymenty związane z bólem, obrzydzeniem, reakcjami na ingerencje fizyczne (np. Rytm 10,

${ }^{46}$ S. Bąk, Dotyk w performansie, [w:] W kulturze dotyku? Dotyk i jego reprezentacje..., ed. cit., s. 305.

${ }^{47}$ Ibidem, s. 304.

${ }^{48}$ Ibidem, s. 306. 
1973; Rytm 5, 1974; Rytm 0, 1974; Thomas Lips / Lips of Thomas, 1975; Art Must Be Beautiful / Artist Must Be Beautiful, 1975; Relacje w przestrzeni, 1976; Batkański barok, 1997).

Jednym z bardziej brutalnych performansów, na który się zdecydowała, był Thomas Lips. Doszło do niego w 1975 roku w Galerie Krinzinger w Innsbrucku, na zaproszenie galerii. Tytuł akcji artystka zaczerpnęła od imienia i nazwiska jednego ze swoich kochanków. Podczas trwającego dwie godziny performansu najpierw spożyła kilogram miodu srebrną łyżka, następnie wypiła litr czerwonego wina wprost z kryształowego kielicha, a po wypiciu rozbiła kieliszek. Czynności te wykonywała w wolnym tempie. Następnie wycięła sobie na rękach szramy, a na brzuchu pięcioramienna gwiazdę. Naga, biczowała się, aż tryskała z niej krew. Nie przestawała aż do momentu, kiedy przestała odczuwać ból. Opowiadała, że czuła się, jakby przekroczyła ścianę cierpienia. Następnie położyła się na podłodze, na krzyżu zbudowanym z bloków lodu. Wówczas opuszczono na nią grzejnik, wcześniej podwieszony drutami pod sufitem. Za przyczyną ciepła, które on emitował, pocięty brzuch kobiety nie przestawał krwawić. Ona sama leżała nieruchomo i oddychała najwolniej, jak umiała, poddając tylną część ciała działaniu przenikliwego zimna, a przednia - przeszywajacego ciepła. Jak zauważa Erika Fischer-Lichte: „W tym performansie chodzi o działania autoreferencyjne, ustanawiające specyficzna rzeczywistość (do czego, nawiasem mówiąc, zawsze prowadzą konkretne działania). Dzięki temu moga one spowodować przemianę artystki i uczestników jej performansu, niezależnie od tego, jaką postać przybierze owa przemiana. Jak jednak zastosować w tym przypadku kryterium fortunności bądź niefortunności? Nie ma wątpliwości, że artystka zjadła zbyt wiele miodu i wypiła zbyt wiele wina oraz faktycznie poraniła swoje ciało, używając żyletki i pejcza. Nie ma też wattpliwości, że kres jej cierpieniom położyli widzowie, którzy podnieśli ja z brył lodu i wynieśli z sali. Czy jednak tym samym performans się udał?" ${ }^{49}$. Wydaje się, że na to pytanie można odpowiedzieć twierdząco, gdyż odbiorcy weszli z artystką w interakcję w ramie działania, którą wyznaczyła im instytucja (galeria sztuki), choć jednocześnie ją przekroczyli. Performerka nie poddawała się biernie skierowanej przeciw niej przemocy, przynoszącej ból i cierpienie, lecz za każdym razem aktywnie jej doświadczała. A cielesność, zmysłowość, ból stały się głównymi składnikami-aktorami dramaturgii tego performansu.

Abramović jest bohaterką nagrodzonego przez publiczność Berlinale amerykańskiego dokumentu Matthew Akersa, pokazującego jej życie

${ }^{49}$ E. Fischer-Lichte, Estetyka performatywności, przeł. M. Borowski, M. Sugiera, Kraków 2008, s. 34. 
i twórczość przez pryzmat jednej z najbardziej spektakularnych akcji artystycznych, która przeprowadziła podczas wielkiej retrospektywy swojej twórczości w nowojorskim Museum of Modern Art w 2010 roku. Przez trzy miesiące na kilka godzin dziennie siadała bez ruchu na krześle w galeryjnej sali. Przysiadali się do niej zwiedzający. Opisywane przez nich później doświadczenie okazało się trudną próbą ciała i emocji. W wyniku tej swoistej, pozbawionej słów psychoterapii pomiędzy artystką a widzami tworzyły się spontaniczne relacje - wiele osób, patrząc jej w oczy, płakało. Co ciekawe, dramaturgia tego doświadczenia artystycznego, a jednocześnie głęboko osobistego, rozgrywała się przede wszystkim na poziomie zmysłu wzroku ${ }^{50}$. „Cielesna współobecność wykonawców i widzów umożliwia przedstawienie, to ona je stanowi. Żeby przedstawienie mogło się odbyć, wykonawcy i widzowie muszą się zebrać na określony czas w określonym miejscu i razem coś przedsięwziąć. [...] Cielesna współobecność oznacza raczej relację między podmiotami. Widzowie to bowiem równorzędni uczestnicy, którzy biorąc udział w grze, powołują do istnienia przedstawienie dzięki swojej fizycznej obecności, percepcji, a także dzięki swoim reakcjom. Tym samym przedstawienie powstaje jako wynik interakcji między aktorami i widzami”" ${ }^{2}$. Najważniejsze jest to, co wydarza się między uczestnikami, rodzaj „duchowej infekcji”, która się między nimi rozprzestrzenia, to, co się wydarza, współprzeżywanie - zarówno na poziomie zmysłowym, jak i afektywnym. Widz nie tylko obserwuje, w jaki sposób dochodzi do zamiany ról między publicznością a aktorami, budowania i niszczenia wspólnoty czy tworzenia bliskości i dystansu, lecz także doświadcza tych procesów na własnej skórze jako uczestnik przedstawienia.

„Dotyk sceny” może się przejawiać także w inny sposób. Eksperyment na poziomie zmysłowego odbioru spektaklu stał się punktem wyjścia do stworzenia dwóch innych ciekawych projektów przez Adama Ziajskiego reżysera i dyrektora Centrum Rezydencji Teatralnej Scena Robocza w Poznaniu. Nie mów nikomu ${ }^{52}$ i Spójrz na mnie ${ }^{53}$ to spektakle, których dra-

${ }^{50}$ Film dokumentalny: Marina Abramović: Artystka obecna / Marina Abramović: The Artist Is Present, USA 2012 / 106', reżyseria: Matthew Akers, Jeff Dupre.

${ }^{51}$ E. Fischer-Lichte, op. cit., s. 46-47.

${ }^{52}$ Nie mów nikomu, scenariusz i reżyseria: A. Ziajski, prapremiera: 25.11.2016, Centrum Rezydencji Teatralnej Scena Robocza, wideo: kolektyw wooom visuals, dźwięk: M. Frycz, kostiumy i scenografia: Grupa Mixer, obsada: J. Frąckowiak, Z. Mądra, K. Mądry, P. Nowak, D. Mroczek-Dąbrowska, A.M. Turek, A. Ziajski.

${ }^{53}$ Spójrz na mnie, reżyseria i scenariusz (na podstawie historii bohaterów): A. Ziajski, prapremiera: 23.02.2018, Teatr Śląski im. Stanisława Wyspiańskiego w Katowicach, premiera poznańska: w ramach cyklu Teatr Powszechny w CK Zamek, scenografia i kostiumy: Grupa Mixer, wizualizacje: F. Czernow, audiodeskrypcja: I. Mrochen, realizacja dźwięku: M. Frycz, M. Lichtański, realizacja światła: T. Wustrau, realizacja projekcji: B. Koźbiał, asystent reżyse- 
maturgia opiera się na grze z naszymi przyzwyczajeniami percepcyjnymi. Spektakl Nie mów nikomu powstał jako manifest wobec zdegenerowania języka oraz obecnych w nim strategii wykluczania i przemocy. Ziajski tak tłumaczy jego genezę: „Jestem głęboko przejęty i zawstydzony stanem językowej wspólnoty. Mam nieodparte wrażenie, że używanie słów i ich znaczeń z coraz większą intensywnością staje się narzędziem zbiorowej konfrontacji, walki wszystkich ze wszystkimi. [...] Do realizacji spektaklu zaprosiłem osoby niesłyszące. Wśród nich jest również jedna osoba niewidoma. $\mathrm{Na}$ początku czułem się zawstydzony tym, jak reaguję i co o nich wiem. Dzisiaj chciałbym krzyknąć: wybieram milczenie! Ale jak tu wykrzyczeć takie wyznanie?" ${ }^{4}$. Reżyser przede wszystkim musiał spróbować wyłączyć jeden ze zmysłów - uznawany przez całe wieki jako jeden z dwóch tzw. zmysłów wyższych słuch - aby wejść w świat aktorów-bohaterów. Osoby niesłyszące czy niedosłyszace moga poczuć się na tym przedstawieniu jako widzowie „docelowi”, a na co dzień pełnosprawni - na swój sposób upośledzeni w jego odbiorze (świadczy o tym już sam sposób gry - całość jest grana w języku migowym z polskimi napisami, publiczność bez zaburzeń słuchu siedzi w wygłuszających słuchawkach). Autentyczności całemu doświadczeniu dodaje to, iż projekt opiera się na osobistym doświadczeniu osób niesłyszacych grajaccych w spektaklu oraz na reportażu Anny Goc Gtusza, który opowiada o trudnej codzienności osób głuchych i niedosłyszących w Polsce ${ }^{55}$. Ziajski dostrzega też aspekt estetyczny - język migowy jest trójwymiarowy, a przez to niezwykle choreograficzny. Reżyser opowiada o izolacji komunikacyjnej, używając bardzo wyrazistych, a zarazem prostych środków scenicznych. Odbiorcy spektaklu dostają wygłuszające dźwięk słuchawki, gdyż ze sceny często rozlega się nieznośny hałas, skierowany do niesłyszacych aktorów, aby poprzez drgania fal dźwiękowych mogli „poczuć” dźwięk. Reżyser jest tu zarazem scenicznym wykonawca (oczywiste jest tu skojarzenie z Tadeuszem Kantorem). Kieruje dźwiękiem i obrazem, kreując spontanicznie,

ra: M. Markiewicz, przewodniczka aktorów niewidomych: A. Fielek, inspicjent: A. Kandziora, producent wykonawczy: M. Długowska-Błach, kierownik techniczny: M. Rokita, projekt plakatu: J. Lemańska, zdjęcia: P. Jendroska, autorka zapachu ciemności: A. Cacha (Olfaktura), obsada: M. Bąk, B. Błaszczyński, G. Kania, A. Machoń, M. Piotrowski, A. Słowik i pies Kora (do lutego 2020) / pies Asari (od lutego 2020), M. Wierzbicki, A. Ziajski oraz M. Frycz, muzyka na żywo i I. Mrochen / M. Markiewicz, audiodeskrypcja na żywo. Znamienne jest, jak wiele osób o różnych specjalizacjach zawodowych było zaangażowanych w powstanie tego projektu; dlatego wymieniam je tu wszystkie.

${ }^{54} \mathrm{http}: / /$ www.scenarobocza.pl/spektakl/1600-nie-mow-nikomu/ (dostęp: 21.04.2021).

${ }^{55}$ Gtusza, reż. A. Goc, „Tygodnik Powszechny” 22.08.2016, https://www.tygodnikpowszechny.pl/glusza-35169 (dostęp: 21.04.2021). Reportaż ma wersję do czytania i do słuchania - w nagraniu zamieszczonym na stronie czasopisma czyta go Anna Dymna, a przekłada na język migowy Magdalena Sipowicz. 
improwizująco nastrój i rytm tego spektaklu. Porusza antena, co powoduje gwałtowne zmiany brzmienia hałasu, a w ślad za dźwiękami idą projekcje monochromatycznych, niebiesko-białych plam oraz linii, rzucane na boczne ściany, które są zbieżne w tonacji i natężeniu z hałasem. Na tylnej ścianie pojawia się napis mówiący o tym, że na pewno nie zrozumiemy kogoś, kto ze ściszonego telewizora mówi do nas po węgiersku. A to jest sytuacja ludzi niesłyszących. Na scenie gra pięcioro niesłyszących wykonawców, przyodzianych w jednolite białe ubiory. Najpierw wykonują oni gimnastykę dłoni przygotowanie do użycia języka migowego. Kolejni bohaterowie podchodza do frontu sceny, zanurzaja ręce w szklanych bańkach (każdej z proszkiem w innym kolorze), barwia swoje ciała i ubrania i zaczynają opowiadać swoje historie. Ich narracja nie jest do słuchania, lecz do oglądania - widzimy migające dłonie i tłumaczenie na ekranie. Historia dwójki bohaterów jest szczególna: pan Kazio jest głuchoniemy i niewidomy, a jego partnerka życiowa, pani Zosia, porozumiewa się z nim, kreśląc palcem na jego dłoni znaki specjalnego języka dla głuchoniemych niewidomych. Dotyk stał się dla nich podstawowym zmysłem komunikacji i - dla niego - jakiegokolwiek kontaktu ze światem zewnętrznym ${ }^{56}$.

Z kolei w Spójrz na mnie na pierwszym planie jest warstwa dźwiękowa przedstawienia, gdyż odwołuje się ono do doświadczeń osób niewidzących i słabowidzących. Ale pojawia się też próba uruchomienia zmysłu węchu Aleksandra Cacha z Olfaktury podjęła próbę stworzenia zapachu ciemności. Twórcy zadbali o jak najbardziej multisensoryczny odbiór, nie zaniedbując tych sprawnie działających zmysłów. Sam plakat do spektaklu został zaprojektowany tak, że na białym tle w samym jego centrum wytłoczono tytuł zapisany alfabetem Braille'a. Ziajski przez kilka miesięcy przeprowadzał wywiady z osobami niedowidzacymi, ociemniałymi i niewidomymi. Na tej podstawie powstał scenariusz. Spośród tych osób wybrał bohaterów spektaklu, reportażu teatralnego, którzy występują na scenie obok aktorów Teatru Ślaskiego. Przedstawił na scenie świat, którego nie da się zobaczyć. Spektakl każdorazowo jest grany z audiodeskrypcja, w związku z czym liczba miejsc jest ograniczona przez liczbę słuchawek. Pięcioro niewidomych bohaterów opowiada o swoim doświadczeniu bycia niewidzialnymi, osamotnionymi i wyizolowanymi przez to, że są niewidomi. To teatr dokumentalny, w którym realne osoby opowiadają o swoich autentycznych doświadczeniach. O swoistej stygmatyzacji osób niewidzących w symboliczny sposób mówią już pierwsze sceny spektaklu, w których zostają przywołane fragmenty Księgi Rodzaju dotyczące stworzenia świata. Odczytuje je syntezator mowy cha-

${ }^{56} \mathrm{~W}$ opisie spektaklu wykorzystano fragmenty recenzji J. Tyszki Zza szyby po wegiersku, 21.12.2016, https://teatralny.pl/recenzje/zza-szyby-po-wegiersku,1802.html (dostęp: 21.04.2021). 
rakterystyczny dla urządzeń lektorskich, którymi posługują się niewidomi. Cytaty z Księgi Rodzaju są przeplatane kolejnymi opowieściami pięciorga bohaterów spektaklu, niewidomych bądź słabowidzących. Choć jesteśmy w stanie rozróżnić ich głosy, to jednak nie przypiszemy tej mowy do konkretnych ciał, gdyż kostiumy i scenografia zaprojektowane przez Grupę Mixer dążą do unifikacji postaci i przestrzeni. Wszyscy aktorzy nosza te same białe kaftany, ich twarze osłaniają mocno przylegające maski, a rzutowane na ściany i podłogę wizualizacje (proste figury geometryczne, kratki, koła, barwne plamy i krzywe linie) powoduja, że ciała aktorów całkowicie zlewaja się z przestrzenia. „Ta «niewidoczność» i anonimowość bohaterów, którą uzyskuje się dzięki efektom wizualnym, jest zamierzona i - tłumaczy Ziajski - ma odnosić się do sytuacji «niewidzialności» osób niewidomych w społeczeństwie"57. Całe przedstawienie rozgrywa się w mroku, a momentami w całkowitej ciemności - to zmusza widzów do przyjęcia takiego modelu percepcji, który wyklucza dominację wrażeń wzrokowych. Przeciwstawione im doznania akustyczne potęguje użycie słuchawek - płynące z nich dźwięki to zarówno muzyka, szumy, jak i głosy aktorów ${ }^{58}$.

W ten sposób kształtuje się estetyka zmysłów; smak, węch i dotyk zyskują wreszcie należne im miejsce. To działania często na styku różnych sztuk - działań performatywnych, teatralnych, z zakresu sztuk wizualnych i innych. Olfaktologia coraz mocniej wkracza do działań artystycznych, a powszechny okulocentryzm zostaje poddany krytyce. Teatr, podobnie jak sfera projektowania i sztuk wizualnych, jest doskonałym polem do działania w obszarze sensoryki. Zmysły budują naszą historię, pamięć, emocjonalność. Za ich sprawą możliwe staja się przekraczanie dominującego porządku i przywrócenie communitas, uruchamiającego wszystkie zmysły.

\section{Dotyk ekranu, czyli immersja zmysłów}

Immersja to pojęcie z zakresu fizyki, pochodzące od łacińskiego słowa immergo - 'zanurzam'. W ściśle naukowym sensie odnosi się do metody stosowanej w mikroskopii polegającej na zwiększeniu zdolności rozdzielczej mikroskopu optycznego poprzez „wypełnienie przestrzeni między przedmiotem a pierwszą soczewką obiektywu mikroskopu przezroczystą cieczą", a w astronomii oznacza „wejście jednego ciała niebieskiego w cień drugiego" ${ }^{59}$. Jednak

${ }^{57} \mathrm{~W}$ opisie spektaklu wykorzystano fragmenty recenzji M. Figzał-Janikowskiej Sceny widzialności, 21.03.2018, https://teatralny.pl/recenzje/sfery-widzialnosci,2313.html (dostęp: 22.04.2021).

${ }_{58}$ M. Figzał-Janikowska, op. cit.

${ }^{59}$ https://sjp.pwn.pl/sjp/immersja;2561260 (dostęp: 20.03.2021). 
współcześnie to pojęcie coraz częściej pojawia się w kontekście technologii i mediów elektronicznych i jest tłumaczone jako proces „zanurzania” czy „pochłaniania” odbiorcy przez rzeczywistość elektroniczna, przez co dochodzi do „zanurzenia zmysłów”. Zwłaszcza sposób percepcji gier komputerowych jest opisywany w kontekście ich immersyjnego odbioru. Gracz znajduje się w pozycji tego, który faktycznie działa na gruncie świata wirtualnego, przy czym bariery fizjologiczne - brak cielesnego bycia w owym świecie - nie maja wpływu na jego zaangażowanie. Światy wirtualne projektowane przez twórców gier komputerowych umożliwiają zanurzenie się w nie. Gracze nadal mają świadomość, że mają do czynienia z medium, które tylko reprezentuje świat, nie tworzy go realnie ${ }^{60}$.

Okres pandemii silnie wpłyną na eksplorację tej właśnie przestrzeni wirtualnego kontaktu między twórcą a odbiorca. Sa to przede wszystkim projekty bardzo oczywiste i od lat już obecne w praktyce wielu instytucji i działaczy kultury (choć na dużo mniejszą skalę niż obecnie), takie jak zapisy spektakli udostępniane online czy wirtualne wystawy na stronie muzeum lub galerii. Jednak niektóre z tych działań przybrały immersyjna formę, bardzo mocno angażując w swój przebieg publiczność. Przykładem są tu spektakle Teatru Usta Usta Republika Ambasada 2.0 $0^{61}$ i 777 online $^{62}$, które miały premierę na platformie Zoom. Nie są one zapisami filmowymi udostępnionymi widzom ani nawet prezentacjami w czasie rzeczywistym, ale interaktywna forma sztuk performatywnych, w której od widza wymaga się aktywności i zaangażowania. Dwa jubileuszowe spektakle (zespół w 2020 roku obchodził dwudziestolecie istnienia) potwierdziły wieloletnia strategię twórczą zespołu, który eksploruje nietypowe przestrzenie i szuka nieoczywistych form kontaktu z widzem.

Choć spektakl Ambasada z 2006 roku pierwotnie wymagał olbrzymiego zaangażowania - od internetowej rejestracji, przez wizytę w jednym z klubów, po jazdę samochodem do wieży zegarowej poznańskiego Zamku i wędrówkę po nim w późnych godzinach nocnych, to ten z 2020 roku wcale mu nie ustępował. To przedstawienie z gatunku site-specific theatre, choć na poziomie eksperymentów teatralnych próby grania w internecie pojawiały się już wcześniej (pierwsza premiera internetowa odbyła się 12 grudnia

${ }^{60}$ K. Prajzner, Tekst jako świat i gra. Modele narracyjności w kulturze wspótczesnej, Łódź 2009, s. 26.

${ }^{61}$ Ambasada 2.0, Teatr Usta Usta Republika, spektakl online w aplikacji Zoom, premiera: 22-24.05.2020, reżyseria: W. Wiński, scenariusz: E. Kaczmarek, K. Macejko, W. Wiński, http://www.ustausta.pl/ambasada-2/ (dostęp: 20.04.2021).

${ }^{62} 777$ online, Teatr Usta Usta Republika, spektakl online w aplikacji Zoom, premiera: 16.10.2020, reżyseria: W. Wiński, scenariusz: E. Kaczmarek, K. Macejko, W. Wiński, http:// www.ustausta.pl/777-online/ (dostęp: 20.04.2021). 
1993 roku za pośrednictwem IRC - Internet Relay Chat, $\operatorname{HamNet}^{63} \mathrm{w}$ adaptacji Stuarta Harrisa rozgrywał się na czacie i uczestniczyli w nim na żywo zarówno aktorzy, jak i zwykli internauci; od 2011 roku jest też realizowany projekt wirtualnej sceny przy użyciu social mediów przez Maxim Gorki Theater, zapoczątkowany premiera spektaklu Effi Briest). Choć kontakt na linii widzowie-aktorzy jest mocno zapośredniczony, to jednak jest jak najbardziej żywy, silny, angażujący i na swój sposób bezpośredni. Ambasada 2.0 nie jest bowiem jedynie odtworzeniem rejestracji spektaklu-zdarzenia, czyli przedstawieniem mediatyzowanym, ale rozgrywanym przy udziale widzów w czasie rzeczywistym, tyle że w wirtualnej przestrzeni.

Paradoksalnie wydaje się zatem, że mimo technologicznego zapośredniczenia zostaje utrzymana w mocy kategoria liveness (nażywośćc4) i mimo dystansu przestrzennego zostaje zachowana autozwrotność komunikacji. Aktorzy grają w czasie rzeczywistym, sa tu i teraz, choć po drugiej stronie ekranu. Ponadto - co mocno wykorzystują twórcy z grupy Usta Usta Republika - mają szansę wchodzić w interakcje, dostrzec w okienkach widzów, zadać im pytanie lub o coś poprosić. Małgorzata Sugiera zauważa, iż współcześnie to pojęcie bardzo rozszerzyło swoje znaczenie i odwołuje się do pojęć „nażywość online” oraz „nażywość grupowa”. Badaczka zwraca uwage na obecną w obu wypadkach „nieprzerwana, technologicznie zapośredniczona (przez Internet czy telefonię komórkowa) współobecność z innymi w tym samym czasie, choć nie w tym samym miejscu. Co istotne, tak poszerzona definicja nażywości obejmuje także interakcje z maszynami, które jako część pętli feedbacku zyskują wrażenie «życia» i sprawczości. [...] dokonało się w tej definicji kolejne istotne przesunięcie: już nie ontologia żywych ciał i nie relacja między mediami a technologiami okazuje się źródłem nażywości, lecz afektywne doświadczenie uczestnika wydarzenia, i to niezależnie od stopnia oraz sposobu technologicznego zapośredniczenia"65. Kolejni badacze tego pojęcia idą jeszcze dalej, proponując zamiast binarnej pary podejście komplementarne, w którym światy realny i wirtualny nie konkurują ze soba, lecz się uzupełniaja.

Widz staje się aktywnym współkreatorem całego wydarzenia. Jego dostęp do przedstawienia warunkują zaplecze i umiejętności technologiczne - wypełnienie formularza na stronie internetowej spektaklu ${ }^{66}$, wymiana

${ }^{63} \mathrm{O}$ tym projekcie pisze T. Kubikowski. Zob. Teatr w sieci, [w:] Kultura i sztuka u progu XXI wieku, red. S. Krzemień-Ojak, Białystok 1997.

${ }^{64}$ P. Auslander, Na żywo czy..., przeł. M. Borowski, M. Sugiera, „Didaskalia. Gazeta Teatralna” 2012, nr 107.

${ }^{65}$ M. Sugiera, Nażywość, [w:] Performatyka: terytoria, red. E. Bal, D. Kosiński, Kraków 2017, s. $146-147$.

${ }^{66} \mathrm{http}: / /$ www.tlustalangusta.pl/ambasada (dostęp: 18.05.2020). 
korespondencji mailowej z Pierwszym Sekretarzem Ambasady, zainstalowanie aplikacji Zoom. Do zainteresowanego udziałem odbiorcy są adresowane liczne techniczne wskazówki: „zainstaluj na swoim laptopie lub komputerze aplikację ZOOM - odradzamy korzystanie z telefonu komórkowego”; „zadbaj o szybkość i stabilność Twojego połączenia internetowego - nie chcielibyśmy się nawzajem znienacka stracić, nieprawdaż?”; „na czas spotkania zapewnij sobie miejsce i spokój, aby nikt Ci nie utrudniał wizyty - uczestnictwo postronnych osób jest niewskazane”; „zaopatrz się w słuchawki (z mikrofonem), aby nic nie umknęło Twojej uwadze”; „poświęć kilka minut, aby skonfigurować komunikator ZOOM - spójrz na krótki poradnik przygotowany przez nasza Administrację". Wśród tych technicznych wskazówek znalazła się i taka, która mówiła: „Zaopatrz się w małą przekąskę oraz có́ słodkiego (batonik, ciastko, czekoladka)". Okazuje się później, że warto było mieć tę przekąskę przygotowana, bo stała się częścią artystycznych działań. Stajemy się współuczestnikami na wielu poziomach spotkania. Poziom techniczny jest tu bazą niezbędną do nawiązania się relacji. Następuje wymiana mailowej korespondencji z Pierwszym Sekretarzem, później zostaje przygotowane miejsce spotkania (ze słodką przekąską włącznie), potem jest wejście w kontakt „na żywo” w wirtualnym środowisku internetu, a jednocześnie wejście dzięki tym narzędziom w realna (choć wirtualna) przestrzeń poznańskiego Zamku. Do tego dochodzą wcześniejsze doświadczenia samego odbiorcy teatralnego: czy widział jakieś inne spektakle zespołu, czy uczestniczył w pierwszej Ambasadzie z 2006 roku, czy interaktywność w kulturze jest dla niego czymś znanym i oswojonym, czy też zupełnym novum. Dramaturgia spektaklu zasadza się na sprzężeniu zmysłów realnych $\mathrm{z}$ ich wirtualnym przetworzeniem. Twórcy staja przed nowymi problemami - od perfekcyjnego opanowania medium przekazu, przez nieco bardziej filmowe niż teatralne kwestie, sposób kadrowania siebie i przestrzeni czy zastosowanie natężenia głosu, po reakcje na zachowania i wypowiedzi samych widzów-współuczestników (czy udzielać im wskazówek technicznych podczas trwania spektaklu, jak zareagować na to, że ktoś w tym czasie piecze ciasto czy karmi dziecko). Te niepokoje i trudy realizacyjne świetnie oddaje Marcin Głowiński, jeden z twórców projektu: „Jest sieć czy nie ma sieci, oto jest teatr w czasach pandemii. Siedemnaście osób na Zoomie. Zaraz zaczynamy, nie, to nie jest spektakl, to jest dziesięć rozpoczynajaccych się co 15 minut spektakli, dla dziesięciu grup widzów [...]. Gdzieś na granicy Niemiec i Luksemburga siedzi reżyser, półelektronowy mózg, WW"67. A zespół na swoim profilu facebookowym po premierze dodaje: „Graliśmy na

${ }^{67} \mathrm{https}: / /$ www.facebook.com/photo.php?fbid=3462480057115219\&set=a. 197707623 592495\&type=3\&theater (dostęp: 15.06.2020). 
żywo, obserwując Wasze reakcje i słuchając Waszych odpowiedzi. [...] Być może teatr w sieci oddziela nas ekranem, ale skraca dystanse"68. W trakcie trwania spektaklu uczestnictwo ma cały czas charakter interaktywny: widzowie wędruja po korytarzach i salach zamkowych, wypełniają ankiety, a ich odpowiedzi sa wykorzystywane $\mathrm{w}$ dalszych działaniach i istotne dla przyznania końcowego azylu w ambasadzie.

W 777 online uczestnictwo publiczności przebiega podobnie - wymaga zaangażowania, interakcji, nieustannej czujności po obu stronach monitora i słuchawek. Spektakl premierowy z 2007 roku, grany na parkingu pod placem Wolności, w założeniu także wymagał zaangażowania publiczności. Najnowsza „zoomowa” realizacja wnosi do sfery odbioru nowy aspekt - dużą intymność spotkania z artystami. Po zalogowaniu na platformę Zoom widz przechodzi na stronę spektaklu, otrzymuje przydomek (odwołujący się do kolorów, np. Czerwona, Biały, Niebieska) i rozpoczyna podróż po wirtualnych pokojach (nazwanych: wiedza, wiara, miłość, zazdrość, zbrodnia czy zdrowie). Widzowie sa przełączani do różnych pokoi, towarzyszą im w tym inni widzowie-uczestnicy, a zdarza się, że czasem są zupełnie sami - twarza w twarz (ekran w ekran) z aktorem. Zoom odbiera, co prawda, możliwość polisensorycznej percepcji (przez ekran nie posmakujemy, nie powąchamy, nie dotkniemy), ale artyści nieustannie odwołuja się do tych pozostałych zmysłów (np. częstują kawą, herbatą lub czymś mocniejszym), wpływając na wyobraźnię odbiorcy.

Immersywność staje się nowym stylem odbioru, częścia procesu wypierania strategii percepcyjnych przez partycypacyjne. Krzysztof Maj proponuje następującą definicję: „Pojęciem, które uwspólnia Coleridge’owskie gorliwe zawieszenie niewiary z Tolkienowską wiara w pozytywny wymiar eskapizmu i Suvinowskim przekonaniem o wyobcowującej sile światotwórstwa, jest i m e r s j a - dosłownie oznaczająca zanurzenie, zagłębienie czy pogrążenie, jednak metaforycznie opisująca pewien szczególny akt odbioru, polegający na zatraceniu się w świecie narracji”"69. Podkreśla za innymi badaczami tego zjawiska, że immersywny odbiór to taki, w którym użytkownik zanurza się w przestrzeni wzrokowej, dźwiękowej i dotykowej, właściwej dla danego środowiska tak mocno, że stwarza się poczucie obecności w wirtualnym świecie, wymykające się fizyczności. Następuje zredukowanie dystansu. Immersja jest transmedialna i polisensoryczna, a jej odbiór można określić mianem światoodczucia, czyli takim partycypowaniem w fikcyjnym świecie, które obejmuje cały zespół charakterystycznych dla niego cech i towarzyszy

\footnotetext{
${ }^{68} \mathrm{https}: / /$ www.facebook.com/tlustalangusta/ (dostęp: 15.06.2020).

${ }^{69}$ K.M. Maj, Czas światoodczucia. Imersja jako nowa poetyka odbioru, „Teksty Drugie” 2015, nr 3, s. 372.
} 
jego rozwojowi ${ }^{70}$. Zastosowanie ma tu pojęcie kultury uczestnictwa, która zakłada aktywność odbiorców utożsamiających się z realiami danego świata i osadzających w nich własne narracje.

$$
* * *
$$

Opisywane zjawiska wpisują się silnie w tzw. zwrot afektywny. Ryszard Nycz definiuje „kulturę afektu” jako kulturę widzianą przez pryzmat jej afektywnego wymiaru oraz taka, która swe specyficzne rysy zawdzięcza zaangażowaniu w afektywne relacje, kształtujące dominujace formy sztuki i literatury. Badacz zwraca uwage na instytucjonalne strategie organizacji i zarządzania „społeczeństwa doświadczenia” czy „społeczeństwa przeżycia”71. Tytułowe „afekty w kulturze” rozumie jako „spektrum afektywnych artykulacji pobudzeń oraz reakcji - o charakterze afektów, emocji, uczuć, nastrojów... - manifestujących się w rozmaitych mediach, rodzajach, gatunkach kultury, a sztuki i literatury w szczególności”72. Dzieła odwołujące się do zmysłu dotyku wydają się mocno wpisywać w tę definicję, gdyż nie tylko odwołują się do intelektualnych i estetycznych kompetencji odbiorcy, lecz także poruszaja jego struktury odczuwania - i to na poziomie zmysłowym, jak i właśnie afektywnym.

Jak zatem widać, współczesna humanistyka, w tym zwłaszcza estetyka, mocno podważa wcześniejsze podziały, kładąc akcent na wielozmysłowy odbiór literatury, sztuki, teatru, działań performatywnych. Niezmiernie istotne są tu kwestie odbiorcy i oddziaływania na jego zmysły. Coraz częściej w swoich doświadczeniach odbiorczych natrafiamy na dzieła - literackie, plastyczne, teatralne, filmowe, performatywne - tak mocno angażujące i przekraczajace definicje tego, co do tej pory leżało w zakresie kompetencji czytelnika i widza, że zostajemy usytuowani na granicy swoich zdolności percepcyjnych i możliwości akceptacji stopnia przekraczania granicy między dziełem a odbiorca. Te przekroczenia są szczególnie widoczne w przywołanych tu przykładach. Niejednorodność, wielopoziomowość, polifoniczność przekazu artystycznego stawiaja odbiorcy coraz bardziej skomplikowane wyzwania. Coraz częściej możemy nie tylko zobaczyć czy wysłyszeć dzieło, lecz także go dotknać, posmakować, powąchać. Zwłaszcza na poziomie dotykowym są to ciekawe doznania - tytułowych chropowatości i szorstkości bądź, w opozycji do nich, gładkości. Niejednokrotnie twórcy w swoich dzia-

${ }^{70}$ Zob. ibidem, s. 382.

${ }^{71}$ R. Nycz, Wstep. Humanistyka wczoraj i dziś (w wielkim skrócie i nie bez uproszczeń), [w:] Kultura afektu - afekty w kulturze. Humanistyka po zwrocie afektywnym, red. R. Nycz, A. Łebkowska, A. Dauksza, seria Nowa Humanistyka, t. XIX, Warszawa 2015, s. 20.

${ }^{72}$ Ibidem, s. 21. 
łaniach odwołują się do zjawiska synestezji, które polega na kojarzeniu ze sobą wrażeń pochodzących od różnych zmysłów, np. dźwięków z kolorami, zapachów ze smakami itp. To zjawisko jest częste zarówno w języku potocznym (np. „,hropowaty głos”, „ciepły kolor”, „słodki zapach”), jak i w języku literackim (np. poezja Charles'a Baudelaire'a i Artura Rimbauda, twórczość Mirona Białoszewskiego ${ }^{73}$. W odbiorze sztuki haptycznej czy nastawionych na wielozmysłową aktywność ekspozycji, performansów i spektakli uruchamia się swoista dramaturgia - zaplanowana przez twórcę, wpisana przez niego w dzieło, ale „aktywowana” dopiero przez odbiorcę traktowanego jako współuczestnika.

\section{BIBLIOGRAFIA}

\section{BIBLIOGRAFIA PODMIOTOWA}

777 online, Teatr Usta Usta Republika, spektakl online w aplikacji Zoom, premiera: 16.10.2020, reżyseria: W. Wiński, scenariusz: E. Kaczmarek, K. Macejko, W. Wiński, http://www.ustausta.pl/777-online/ (dostęp: 20.04.2021).

Ambasada 2.0, Teatr Usta Usta Republika, spektakl online w aplikacji Zoom, premiera: 22-24.05.2020, reżyseria: W. Wiński, scenariusz: E. Kaczmarek, K. Macejko, W. Wiński, http://www.ustausta.pl/ambasada-2/ (dostęp: 20.04.2021).

Brama Poznania, https://bramapoznania.pl/oferta-dla-rodzin-z-dziecmi (dostęp: 23.04.2021).

Centrum Nauki Kopernik, https://www.kopernik.org.pl/wydarzenia (dostęp: 23.04.2021).

Dotknać obrazu - Malczewski, Szymborska, Antoniszczak, Muzeum UJ Collegium Maius, 14.10 - 6.12.2013, http://www.dotknijkultury.pl/pl/poprzednie-edycje/2013/ wydarzenia/wystawa-dotknac-obrazu (dostęp: 7.07.2020).

Film dokumentalny: Marina Abramović: Artystka obecna / Marina Abramovic: The Artist Is Present, USA 2012 / 106', reżyseria: M. Akers, J. Dupre.

https://muzeumkrakowa.pl/muzeum-bez-barier (dostęp: 20.04.2021).

https://objectlessons.space/posts/2019/sissel-tolaas (dostęp: 10.04.2021). https://sensorymaps.com/?projects=smellwalking-practices-and-influences (dostęp: 10.04.2021). https://sztukawciemno.pl/ (dostęp: 20.04.2021).

https://sztukawciemno.pl/o-projekcie/ (dostęp: 20.04.2021).

Multimedialne Muzeum, https://multimedialnemuzeum.pl/ (dostęp: 23.04.2021).

Muzeum Bajek, Baśni i Opowieści MuBaBaO, https://www.facebook.com/Muzeum-Bajek-Ba\%C5\%9Bni-i-Opowie\%C5\%9Bci-Storyteller-Museum-128032343954199; http:// mubabao.pl/ (dostęp: 23.04.2021).

Muzeum Krakowa, https://muzeumkrakowa.pl/cykle/program-edukacyjny-towarzyszacy-wystawie-w-chocholim-tancu (dostęp: 23.04.2021).

Muzeum Powstania Warszawskiego, https://www.1944.pl/artykul/tajne-komplety-czyli-zwiedzaj-muzeum-inaczej-ni,5114.html (dostęp: 23.04.2021).

${ }^{73}$ https://encyklopedia.pwn.pl/haslo/synestezja;3982085.html (dostęp: 25.04.2021). 
Nie mów nikomu, scenariusz i reżyseria: A. Ziajski, prapremiera: 25.11.2016, Centrum Rezydencji Teatralnej Scena Robocza.

Spójrz na mnie, reżyseria i scenariusz (na podstawie historii bohaterów): A. Ziajski, prapremiera: 23.02.2018, Teatr Ślaski im. Stanisława Wyspiańskiego w Katowicach, premiera poznańska: w ramach cyklu Teatr Powszechny w CK Zamek.

Wystawa (Nie) Dotykaj! Haptyczne aspekty sztuki polskiej po 1945 roku prezentowana w Centrum Sztuki Współczesnej w Toruniu, 11.04 - 17.05.2015, https://csw.torun. $\mathrm{pl} /$ sztuka/wystawy/wystawa-nwystawa-nie-dotykaj-haptyczne-aspekty-sztuki-polskiej-po-1945-rokuie-dotykaj-haptyczne-aspekty-sztuki-polskiej-po-1945-roku-4090/ (dostęp: 7.07.2020).

Wystawa To czuć! Projektowanie dla zmysłów, 23.03.2017, Galeria R+ w Szczecinie, https://www.facebook.com/pg/galeriarplus/photos/ (dostęp: 10.04.2021).

Zamek w Kórniku, https://kornik.travel/pl/obiekty/zwiedzanie/zamek=-w-korniku?gclidCj0KCQjw9_mDBhCGARIsAN3PaFPpwAVNuWd0HkhoutucM8fSsYaBxs8vW3p5 AsmInyRsLX2purAgLHQaAugTEALw_wcB (dostęp: 20.04.2021).

BIBLIOGRAFIA PRZEDMIOTOWA

Arystoteles, O duszy, przeł. P. Siwek, Warszawa 1992.

Aschenbrenner K., Jak możliwa jest sztuka?, przeł. M. Gołaszewska, [w:] Eseje o pięknie. Problemy estetyki i teorii sztuki, red. K. Wilkoszewska, Warszawa-Kraków 1988, [także w:] Eidos sztuki, red. M. Gołaszewska, Kraków 1988.

Auslander Ph., Na żywo czy..., przeł. M. Borowski, M. Sugiera, „Didaskalia. Gazeta Teatralna” 2012, nr 107.

Bal M., Wędrujace pojęcia w naukach humanistycznych. Krótki przewodnik, przeł. M. Bucholc, Warszawa 2012.

Bałus W., Dotykanie wzrokiem. O pojęciu haptyczności w klasycznej nauce o sztuce, „Konteksty” 2019, nr 4.

Baumgarten A.G., Metafizyka, przeł. i oprac. J. Surzyn, seria Biblioteka Europejska, Kęty 2012.

Bak S., Dotyk w performansie, [w:] W kulturze dotyku? Dotyk i jego reprezentacje $w$ tekstach kultury, red. A. Łebkowska, Ł. Wróblewski, P. Badysiak, Kraków 2016.

Człowiek posiada więcej niż 5 zmysłów, 16.06.2016, https://joemonster.org/art/36446 (dostęp: 3.08.2020), źródło anglojęzyczne: D. Hiskey, Humans have a lot more than five senses, 16.07.2010, http://www.todayifoundout.com/index.php/2010/07/humans-have-a-lot-more-than-five-senses/ (dostęp: 3.08.2020).

Encyklopedia PWN, https://encyklopedia.pwn.pl/haslo/muzeum;3944738.html (dostęp: 23.04.2021).

Encyklopedia PWN, https://encyklopedia.pwn.pl/haslo/synestezja;3982085.html (dostęp: 25.04.2021).

Figzał-Janikowska M., Sceny widzialności, 21.03.2018, https://teatralny.pl/recenzje/ sfery-widzialnosci,2313.html (dostęp: 22.04.2021).

Fischer-Lichte E., Estetyka performatywności, przeł. M. Borowski, M. Sugiera, Kraków 2008.

Folga-Januszewska D., Muzeum: definicja i pojęcie. Czym jest muzeum dzisiaj?, „Muzealnictwo" 2008, nr 49.

253 Szorstki i chropowaty dotyk - o dramaturgii zmysłów 
Ghirardo D., Architektura po modernizmie, Toruń 1999.

Gtusza, reż. A. Goc, „Tygodnik Powszechny” 22.08.2016, https://www.tygodnikpowszechny.pl/glusza-35169 (dostęp: 21.04.2021).

Gołaszewska M., Estetyka pięciu zmysłów, Warszawa-Kraków 1997.

Hegel G.W.F., Wyktady o estetyce, t. 1, przeł. A. Landman, J. Grabowski, Biblioteka Klasyków Filozofii, Warszawa 1964.

Herbert Z., Podróż, [w:] idem, Elegia na odejście, Wrocław 1993.

http://www.scenarobocza.pl/spektakl/1600-nie-mow-nikomu/ (dostęp: 21.04.2021).

http://www.tlustalangusta.pl/ambasada (dostęp: 18.05.2020).

https://www.facebook.com/photo.php?fbid=3462480057115219\&set=a. 19770

7623592495\&type=3\&theater (dostęp: 15.06.2020).

https://www.facebook.com/tlustalangusta/ (dostęp: 15.06.2020).

Inny słownik języka polskiego, t. I: A...Ó, red. M. Bańko, Wydawnictwo Naukowe PWN, Warszawa 2000.

Inny słownik języka polskiego, t. II: P...Ż, red. M. Bańko, Wydawnictwo Naukowe PWN, Warszawa 2000.

Koton-Czarnecka M., Zmysty zwierzat sa niesamowite. Jak postrzegaja świat?, „National Geographic Polska” 25.02.2020, https://www.national-geographic.pl/artykul/ zmyslowa-ostrosc (dostęp: 8.03.2020).

Kozak P., Wychować Boga. Estetyka antropologiczna Alexandra Gottlieba Baumgartena na tle myśli niemieckiej pierwszej połowy XVIII wieku, Warszawa 2013.

Kubikowski T., Teatr $w$ sieci, [w:] Kultura i sztuka u progu XXI wieku, red. S. Krzemień-Ojak, Białystok 1997.

Maj K.M., Czas światoodczucia. Imersja jako nowa poetyka odbioru, „Teksty Drugie” 2015, nr 3.

Mączyńska-Frydryszek A., Jaskólska-Klaus M., Maruszewski T., Psychofizjologia widzenia, red. R. Bartel, Poznań 2001.

Nycz R., Wstęp. Humanistyka wczoraj i dziś (w wielkim skrócie i nie bez uproszczeń), [w:] Kultura afektu-afekty w kulturze. Humanistyka po zwrocie afektywnym, red. R. Nycz, A. Łebkowska, A. Dauksza, seria Nowa Humanistyka, t. XIX, Warszawa 2015.

Piotrowski P., Muzeum krytyczne, Poznań 2011.

Podgórski M., Ucieczka od wizualności i jej społeczne konsekwencje. Fenomen estetyki haptycznej, Poznań 2011.

Popczyk M., Estetyczne przestrzenie ekspozycji muzealnych. Artefakty przyrody i dzieła sztuki, Kraków 2008.

Prajzner K., Tekst jako świat i gra. Modele narracyjności w kulturze współczesnej, Łódź 2009, s. 26.

Ripa C., Ikonologia, Kraków 2013.

Rivière G.H., La muséologie selon, Paris 1989.

Rostkowska A., Haptyczne dzieło sztuki, [w:] Materia sztuki, red. M. Ostrowicki, Kraków 2010.

Shusterman R., Estetyka pragmatyczna. Żywe piękno i refleksja nad sztuka, red. nauk. A. Chmielewski, przeł. A. Chmielewski i in., Wrocław 1998.

Stownik języka polskiego PWN, https://sjp.pwn.pl/sjp/chropawy;2448697.html (dostęp: 23.05.2020). 
Stownik języka polskiego PWN, https://sjp.pwn.pl/sjp/immersja;2561260 (dostęp: 20.03.2021).

Stownik języka polskiego PWN, https://sjp.pwn.pl/slowniki/szorstki.html (dostęp: 23.05.2020).

Stownik synonimów, https://antonimy.net/antonim/chropowaty (dostęp: 23.05.2020).

Stownik synonimów, https://synonim.net/synonim/szorstki (dostęp: 23.05.2020).

Smolińska M., (Nie) dotykaj! Haptyczne aspekty sztuki polskiej po 1945 roku, https:// csw.torun.pl/sztuka/wystawy/wystawa-nwystawa-nie-dotykaj-haptyczne-aspekty-sztuki-polskiej-po-1945-rokuie-dotykaj-haptyczne-aspekty-sztuki-polskiej-po-1945-roku-4090/ (dostęp: 20.04.2021).

Smolińska M., Wprowadzenie, [w:] eadem, Haptyczność poszerzona. Zmyst dotyku w sztuce polskiej drugiej połowy XX i poczatku XXI wieku, Kraków 2020.

Stefanik M., Kamel M., Muzea i wystawy interaktywne w Polsce-wspótczesna atrakcja turystyczna, „Turystyka Kulturowa” 2013, nr 8.

Sugiera M., Nażywość, [w:] Performatyka: terytoria, red. E. Bal, D. Kosiński, Kraków 2017.

Tatarkiewicz W., Dzieje sześciu pojęć: sztuka, piękno, forma, twórczość, odtwórczość, przeżycie estetyczne, red. E. Nowakowska, Warszawa 1975.

Tkaczyk K., Johann Gottfried Herder. Sensualistyczny bunt wobec klasycznej estetyki, [w:] W kulturze dotyku? Dotyk i jego reprezentacje $w$ tekstach kultury, red. A. Eebkowska, Ł. Wróblewski, P. Badysiak, Kraków 2016.

Tyszka J., Zza szyby po węiersku, 21.12.2016, https://teatralny.pl/recenzje/zza-szyby-po-wegiersku,1802.html (dostęp: 21.04.2021).

Monika Błaszczak - adiunkt w Zakładzie Estetyki Literackiej Instytutu Filologii Polskiej na Uniwersytecie im. Adama Mickiewicza w Poznaniu. Literaturoznawca, teatrolog i kulturoznawca. Jej zainteresowania badawcze obejmuja: estetykę literacka i performatywna, współczesny i najnowszy dramat i teatr, estetykę odbioru i strategie odbiorcze we współczesnym teatrze i sztukach performatywnych, kategorie estetyczne $\mathrm{w}$ ujęciu interdyscyplinarnym i transdyscyplinarnym, łączącym perspektywy: literaturoznawczą, kulturoznawczą i teatrologiczną oraz praktyczne aspekty kultury, takie jak: zarządzanie w kulturze, sztuka autoprezentacji, kuratorstwo kulturalne. ORCID: 0000-0002-3942-8026. Adres e-mail: <monika.blaszczak@amu.edu.pl>.

Monika Błaszczak - PhD, lecturer in the Department of Literary Aesthetics of the Institute of Polish Philology at Adam Mickiewicz University in Poznan. Literary scholar, theater and culture expert. Her research interests include literary and performative aesthetics, contemporary and recent drama and theater, the aesthetics of reception and reception strategies in contemporary theater and performing arts, aesthetic categories from an interdisciplinary and transdisciplinary perspective, combining literary, cultural and theater perspectives, as well as practical aspects of culture, such as management in culture, the art of self-presentation, cultural curatorial. ORCID: 0000-0002-3942-8026. E-mail address: <monika.blaszczak@amu.edu.pl>. 
